\title{
Austerity policies, economic growth and fiscal balance: lessons from Slovenia*1
}

\author{
Petra Došenović Bonča ${ }^{2}$, Maks Tajnikar ${ }^{3}$
}

\begin{abstract}
The authors investigate the impact of austerity policies by empirically analysing the crowding out effect, the Ricardian equivalence principle, and the effect of domestic competitiveness on economic growth in Slovenia. Using the narrative method, the authors researched determinants of economic growth and the impact of fiscal policies on the empirical relationship between state debt and economic growth. The authors show that Slovenia has executed austerity measures over short time periods only, and argue that one cannot find convincing evidence that the enacted austerity policy created the theoretically and empirically expected effects. The authors show that the revival of economic growth was independent of enacted austerity policies. Such economic growth has also benefitted the general budget balance and fiscal position of Slovenia.
\end{abstract}

Key words: austerity policy, growth, state debt, Slovenia

JEL classification: E12, E6

\section{Introduction}

In this paper, the authors discuss the role and impact of austerity policies on macroeconomic developments in Slovenia following the economic crisis in 2009 and address the question of whether austerity policies were indeed systematically

\footnotetext{
* Received: 16-01-2018; accepted: 04-06-2018

1 This work was supported by the Slovenian Research Agency [grant number P5-0117 (A)].

${ }^{2}$ Associate Professor, University of Ljubljana, Faculty of Economics, Kardeljeva ploščad 17, 1000 Ljubljana, Slovenia. Scientific affiliation: economic theory, health economics. Phone: +38615892 448. Fax: +38615892 698. E-mail:petra.d.bonca@ef.uni-lj.si. Personal website: http://www.ef.uni-lj.si/person/Petra-Dosenovic-Bonca (corresponding author).

${ }^{3}$ Full Professor, University of Ljubljana, Faculty of Economics, Kardeljeva ploščad 17, 1000 Ljubljana, Slovenia. Scientific affiliation: economic theory, entrepreneurship, health economics. Phone: +38615892 574.Fax:+38615892698.E-mail: maks.tajnikar@ef.uni-lj.si.Personal website: http://www.ef.uni-lj.si/osebe/Maks-Tajnikar.
} 
enacted. They use the narrative method and their analysis is based on the one hand on the theory behind the impact of austerity on the state budget (e.g. Boyer, 2012; Cottrell, 2013: 107-108; Konzelmann, 2014) and on the other hand on published empirical findings about spending- versus tax-based consolidations of public debt and measures of maintaining economic growth (e.g. Ramey, 2016).

The authors' hypothesis is that the case of Slovenia does not confirm the theoretically expected effects of austerity policies and does also not support the prevailing empirical results indicating that fiscal consolidations (austerity) based upon expenditure cuts are much less costly than those performed on the tax side (Alesina, Favero and Giavazzi, 2018). The authors thus examine the hypothesis that austerity policies can improve the general budget balance without sacrificing economic growth if the adopted economic policies integrate Keynesian demand management policies and if they focus on the dynamics of those effective demand elements that are to a lesser extent influenced by austerity policies.

To do so, the authors in their literature review first show the dilemmas in current research that motivate their analysis. In the third section they show the case of Slovenia and the data and methodology used for the purpose of this paper. The fourth section of the paper challenges the validity of the three key theoretical effects of austerity and argues based on the analysis of fiscal policies adopted in Slovenia and the achieved economic growth that fiscal consolidations based on the tax side are much less costly than those performed upon expenditure cuts. The fifth section provides the discussion of key findings. Policy recommendations are debated in the concluding section.

\section{Literature review}

Studies of the austerity policy can be divided into two groups, i.e. those that deal with the theories behind austerity and those that are empirical (e.g. Pržiklas Družeta and Škare, 2017).

Austerity policies have strong theoretical foundations (e.g. Perotti, 1996; Chang, 2012; Konzelmann, 2014; Krugman, 2012; Crotty, 2012; Stiglitz, 2013 and Galbraith, 2014). There are thus strong theoretical arguments that austerity measures can achieve the desired results (e.g. Boyer, 2012; Cottrell, 2013: 107-108; Konzelmann, 2014). Economic growth is expected to revive by restoring the general government balance through the interaction of three different effects (Boyer, 2012: 296-297).

The first is the crowding-out effect of public deficits that emerges due to competition between private and public financing. A reduction of state borrowing is expected to decrease the crowding-out effect by inducing a lower interest rate and encouraging more productive private spending and investment. 
The second refers to the Ricardian equivalence principle and the expectation of rational actors that less taxation will be required in the future if the public deficit is reduced by lowering public spending. Because taxpayers anticipate they will have to pay lower taxes in the future, they lower their savings reserved for the payment of future taxes and increase their current consumption.

The third effect relates to domestic competitiveness and the fact that an improvement in the trade balance can outweigh the negative impact of the contraction of the public sector. Namely, lower public spending and the resulting depressed domestic market are expected to redirect firms towards foreign markets, thereby increasing exports, acting as a signal of wage austerity and thus discouraging imports.

To evaluate the impact and results of implemented austerity measures one thus has to investigate whether empirical data indeed confirm the crowding out effect, the Ricardian equivalence principle and domestic competitiveness effect on economic growth in Slovenia.

There is a number of empirical studies investigating austerity policies (Giavazzi and Pagano, 1990; Alesina et al., 1998; Blanchard and Perotti, 2002; Alesina and Ardagna, 1998, 2010; Romer and Romer, 2010; Matsaganis and Leventi, 2014). The expansionary fiscal adjustment hypothesis is typically used to argue in favour of austerity policy measures (Giavazzi and Pagano, 1990). A common hypothesis of proponents of austerity is that the fiscal adjustments based on spending cuts rather than fiscal adjustment based on tax are more efficient in reducing public debt and that they do not impede economic growth. It is the aim of this paper to investigate the relationship between fiscal policies that are used to enact austerity, managing public deficits and economic growth using the case of Slovenia. This is valuable particularly because the hypothesised effects of austerity are usually based on simplified scenarios that do not reflect complex realities. They are also tested on a large number of economies thereby neglecting specific features of individual countries and the determinants of their reactions to the economic environment. This is particularly important because the impacts of austerity measures are not the same in all stages of the economic cycle (Auerbach and Gorodnichenko, 2012).

\section{Conception of analysis}

The economic conditions that have developed in Slovenia during the 2009 crisis are very similar to those in other Southern European countries (e.g. Cambridge Journal of Economics, 2013). As evident from Figure 1, weak recovery from the initial shocks in 2009 characterised the Slovenian economy in 2010 and 2011 when Slovenia had low but positive GDP growth. This trend reversed in 2012. The decline in economic activity continued throughout 2013. In 2014, however, GDP growth was positive ( 3.1 percent) and was among the highest in the euro zone. As 
shown by Figure 1, unemployment has increased following the 2009 crisis (2008: 4.4 percent; 2013: 10.1 percent). As economic growth revived, unemployment started to decrease. As illustrated by GDP per capita also the standard of living declined in 2009. It temporarily improved in 2011 and has been steadily increasing since 2014 when economic revival started.

Figure 1: GDP real growth rates, unemployment rates and GDP per capita, Slovenia, 2001-15

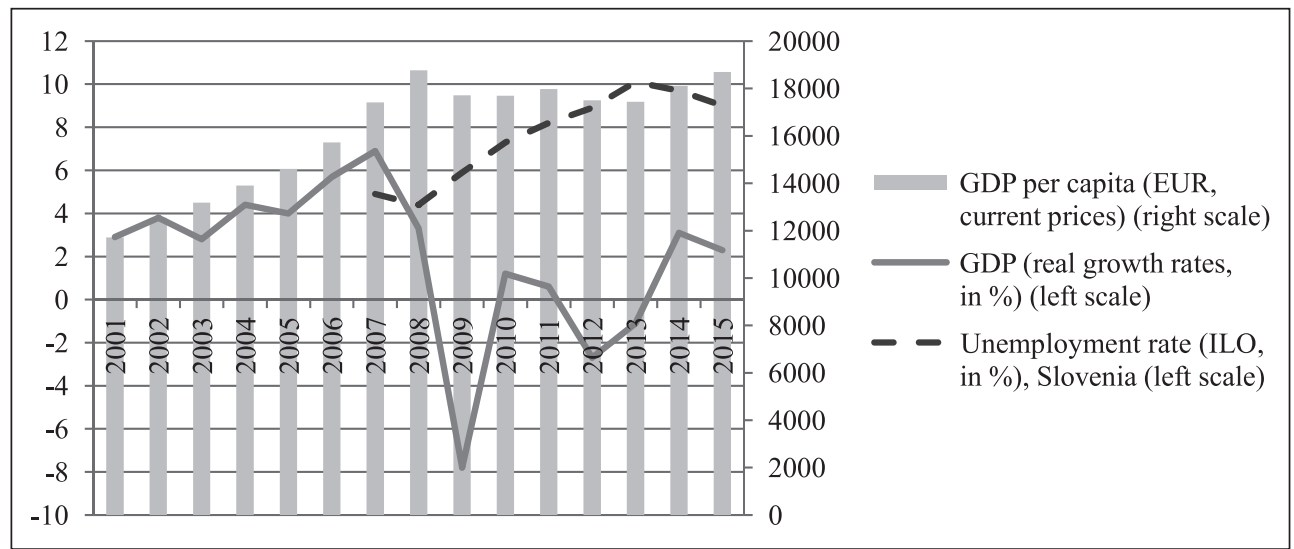

Source: SORS (2017)

The onset of the economic crisis in 2008 coincides with the worsening of the general government deficit problems (Figure 2). The nearly balanced budget changed into general government budget deficits exceeding EUR 2 billion annually in the 2009-11 period. The deficit declined notably in 2012 but rose again to the record EUR 5.4 billion in 2013. Since then the general government deficit has been declining.

Given that general government revenues have been increasing ever since their 2009 drop with highest increases in 2014 and 2015, they negatively impacted the budget deficit only in 2009. In the following years, they reduced the deficit. The fluctuations of the deficit since 2009 can thus be attributed mainly to the dynamics of general government expenditures. 
Figure 2: Consolidated general government revenue and expenditure (in mio EUR) and general government deficit (in mio EUR), Slovenia, 2005-15

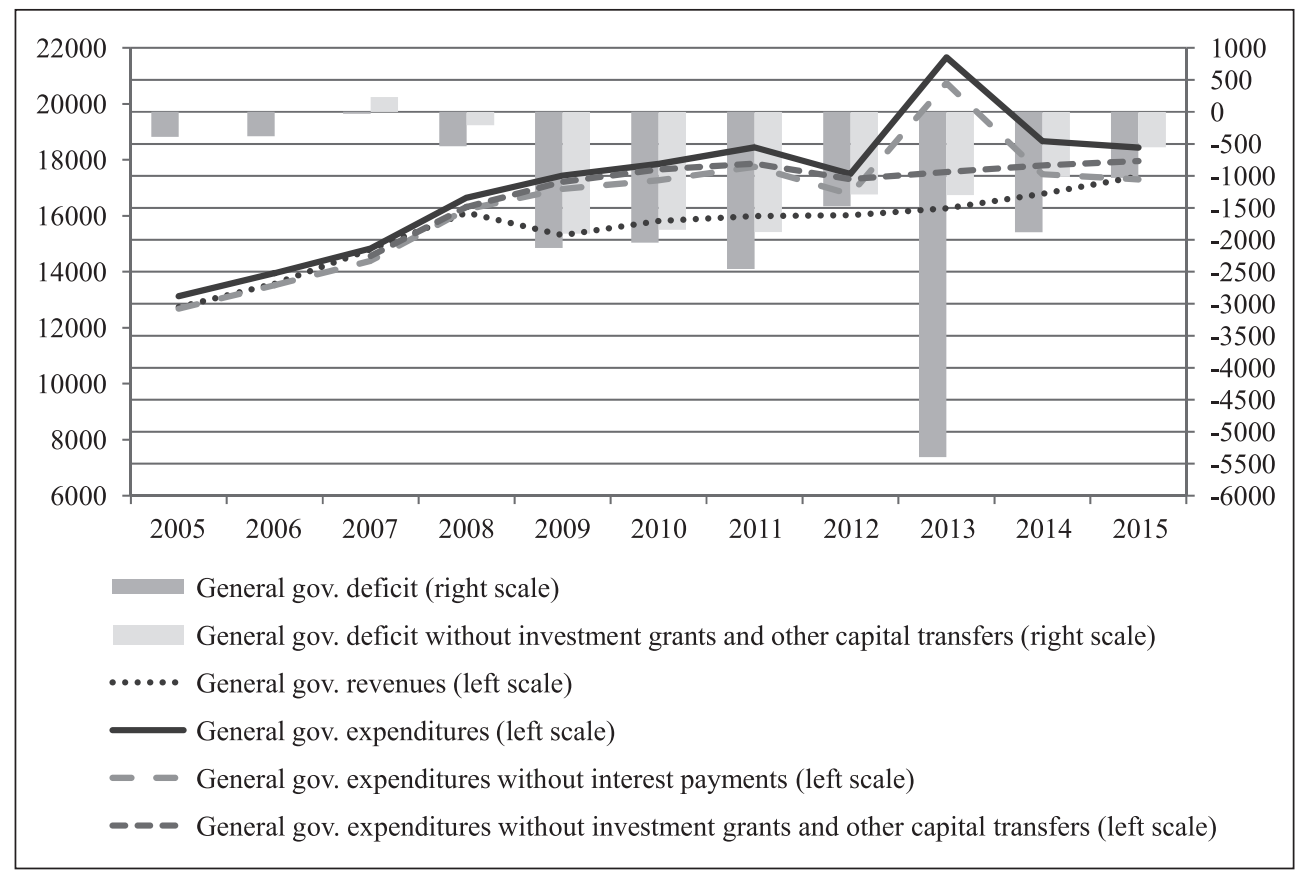

Source: SORS (2017)

The major decline of expenditures in 2012 resulted in lower deficit but their notable increase in 2013 created the largest deficit in the analysed period. The lower deficit of 2015 is a consequence of both lower general government expenditures and increasing revenues.

A clearer link between the general government deficit and economic growth is, however, revealed only if we exclude investment grants and other capital transfers from total general government expenditures. These two expenditure categories were particularly high in 2013 (EUR 4.1 billion) and 2014 (EUR 0.87 billion) when bank restructuring and resolution procedures were carried out. The dynamics of general government expenditures without investment grants and other capital transfers reveals that expenditures declined only in 2012 and they were increasing in all other years of the observed period. The general government deficit that excludes the discussed capital transfers has continued to decline since 2013 despite the rising government expenditures. The decline of the general government deficit can thus be attributed to the growth of general government revenues, particularly since 2013.

In Slovenia, austerity policy was thus implemented only in 2012. As shown in later sections of the paper in Table 1, the 2012 austerity package generated savings 
through expenditure cuts amounting to EUR 980 million (2.72 percent of GDP) or to EUR 588 million (1.63 percent of GDP) if we exclude other capital transfers and investment grants.

The emergence of the general government deficit in 2008, when GDP growth was still positive, and its increase in 2009 have been key reasons for lower credit ratings of Slovenia by the leading rating agencies, reduced accessibility to debt financing for the general government sector and the higher cost of public debt. These problems were also the strongest arguments in 2012 to make a dramatic shift in economic policy towards austerity in order to battle the economic crisis. This pessimistic positioning of Slovenia by international institutions was not based on the actual circumstances given that GDP growth became positive in 2010 and public and publicly guaranteed gross external debt represented only 42.3 percent of GDP in 2009 (Bank of Slovenia, 2017) (see also Figure 3). Slovenia was one of the least indebted countries in 2009 when crisis came to full power. In 2012, Slovenia's gross external debt was at 115.1 percent of GDP while the average in the euro area amounted to 211.1 percent of GDP. In Slovenia, public and publicly guaranteed debt (EUR 19.2 billion) amounted to 54.1 percent of GDP. In the euro area, on the other hand, it equalled 90.6 percent of GDP (IMAD, 2013).

In Slovenia, few arguments based on facts, evidence and reason were used to support the process of adopting the austerity package. Instead, policy makers relied on spreading fear and warned against increased public debt, EU sanctions and the Troika visit.

Even though austerity policy was implemented only in 2012, austerity continues to be advocated. However, the arguments were not used to cut general government expenditures but for other changes such as privatisation of state owned companies, restructuring of the public sector, greater labour market flexibility and bank restructuring. Furthermore, in Slovenia no empirical investigations such as the examples of Reinhard and Rogoff (2009) and Alesina and Ardagna (1998, 2009) were undertaken to support the development of austerity packages. Authors of this paper thus attempt to verify using macroeconomic data for Slovenia whether the three theoretically expected results of austerity policy - the crowding out effect, the Ricardian equivalence principle and domestic competitiveness effect - indeed emerged due to implemented austerity measures in 2012. In so doing, they on the one hand consider theoretical foundations that economic growth is expected to revive by restoring the general government balance through the interaction of three different effects and on the other hand, they take into account the fact supported by empirical data that in Slovenia austerity was strictly implemented only in 2012 . This one-time shock in the Slovenian economy provides a unique insight into the validity of the hypothesis that fiscal adjustments based on spending cuts compared with fiscal adjustment based on tax are more efficient in reducing public debt and that they also do not impede economic growth. 


\section{Empirical data and analysis}

Crowding-out effect of public deficits impacts investment, the Ricardian equivalence principle refers to the impacts on household consumption while the effects on domestic competitiveness are crucial for the level of exports. We examine whether all three effects of austerity in Slovenia impacted effective demand thereby encouraging economic growth.

\subsection{Crowding-out effect of the public deficits and investment}

At first glance, data for Slovenia (see Figure 3) do indicate the presence of the crowding-out effect of the public deficit.

Figure 3: The structure and size (in million $€$ ) of external debt, Slovenia, 2001-15

Public and publicly guaranteed
debt: long term - share (left scale)

Source: Bank of Slovenia (2017)

From 2008 to 2015, public and publicly guaranteed debt rose by EUR 19.6 billion while non-guaranteed private sector external debt declined by EUR 15 billion. Gross external debt thus increased by EUR 4.6 billion and has remained fairly stable since 2009 at around EUR 40-46 billion (Bank of Slovenia, 2017). According to theoretical assumptions, increased indebtedness of the state leads to increased interest rates and thus smaller accessibility to debt funding for the private sector. Both changes are expected to have a negative impact on investments.

However, reductions of private debt cannot be attributed merely to increased public debt. Private sector debt in fact began to fall because in the period from 2001 
to 2008 the private sector had accumulated too much debt and due to the global financial crisis firms were forced to reduce their indebtedness in order to survive. From 2001 to 2008 Slovenia's gross external debt increased by EUR 29.9 billion. This rise was largely due to the private sector as its debt went up by EUR 26.9 billion (Bank of Slovenia, 2017). In the 2004-2008 period alone, the ratio of debt to total liabilities and shareholders' equity of Slovenian firms increased from 0.88 to 1.46 (Eurostat, 2017). Slovenian firms exhibited significantly higher indebtedness at the start of the crisis compared to firms in euro area countries (see Figure 4, left scale).

Figure 4: Debt-to-equity ratio of firms in Slovenia and EU18 and real GDP growth to real interest rate ${ }^{*}$ ratio for Slovenia, 2004-15

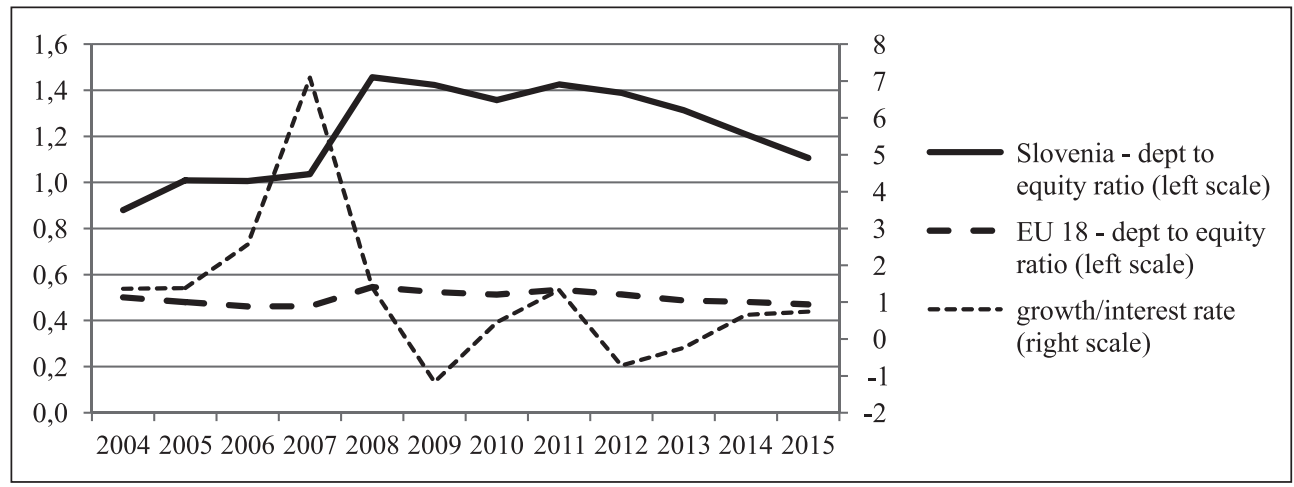

Note: * for non-financial corporations on new loans in domestic currency; loans over EUR 1 million, floating and up to 1 year initial rate fixation.

Source: Eurostat (2017), SORS (2017), Bank of Slovenia (2017)

According to the crowding-out effect of the public deficits increasing state indebtedness is also expected to impact the interest rates for non-financial corporations.

As shown by Figure 5, real interest rates rose in 2009 and in the 2012-2014 period and they declined more substantially in 2011 and 2015. A large increase of the general government deficit in 2009 was thus, according to expectations, accompanied with an interest rate rise. The same conclusion can be drawn also for 2013. Interestingly, however, in 2012 when austerity was executed to the largest degree the interest rates increased notably. Furthermore, in 2015 interest rates fell again but in the same year the state indebtedness declined only slightly. In 2015, there was a more significant decline of private debt despite lower interest rates. It is also important to note that interest rates started to rise already in 2008 before GDP declined and prior to the large increase of the general government deficit in 2009. Similarly, interest rates continued to rise in 2014 when GDP growth stated to revive 
and deficit reduced. The above discussion thus implies that some other factors aside from the public deficits played a vital role in the interest rate fluctuations.

Figure 5: Real interest rates for non-financial corporations on new loans* in domestic currency, Slovenia, 2003-15

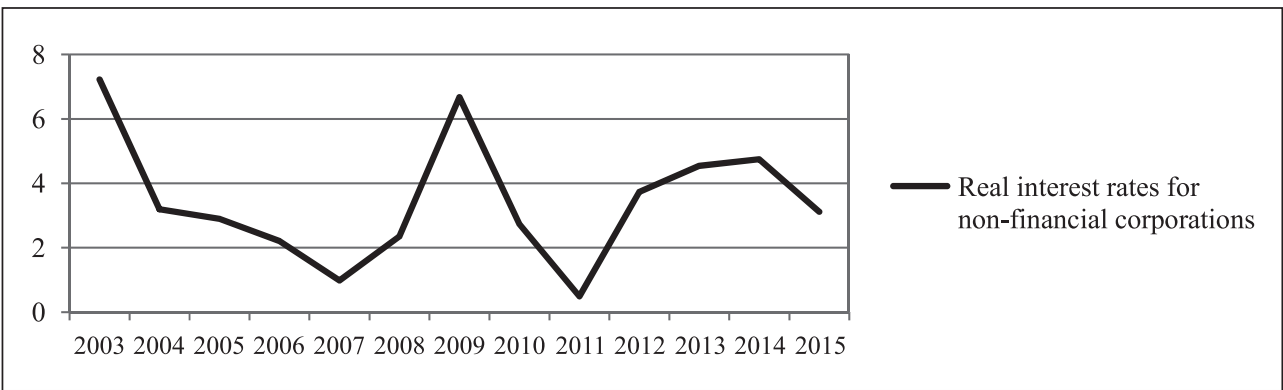

Note: *Loans over EUR 1 million, floating and up to 1 year initial rate fixation

Source: Bank of Slovenia (2017)

A very important aspect of Slovenian firms' indebtedness at the start of the crisis is revealed by the ratio of real GDP growth and the real interest rate (see Figure 4, right scale). In the period from 2004 until 2008, this ratio exceeded unity for Slovenian non-financial corporations (average value was 2.76). If we draw an analogy with the general government sector debt (e.g. Taylor et al., 2012), this implies that firms were able to generate positive cash flows and increase their ability to borrow even though their debt was rapidly rising. With the onset of crisis in 2009, the ratio of real GDP growth and the real interest rate dropped significantly to below 1 (average value in the 2009-2015 period was 0.15). In this way circumstances, in which firms no longer generate sufficient cash flows developed, forcing them to divest, and putting the most indebted firms at a risk of insolvency and bankruptcy. In a very short period, firms' borrowing power plummeted.

Also the implementation of austerity measures in 2012 did not create more favourable conditions for borrowing of firms. The average value of the ratio of real GDP growth and the real interest rate remained below 1, i.e. 0.11 , in the entire 2012-2015 period despite the fact that average GDP growth in this period was higher than in the 2009-2011 period. Real interest rates namely rose significantly despite the expectation that the implementation of austerity measures in 2012 would result in lower interest rates. Also this short period of austerity thus fails to provide substantive evidence about the presence of the crowding-out effect of the public deficits.

This discussion demonstrates that in Slovenia the private sector would have been forced to reduce its indebtedness even if public debt had remained stable. The entire 
period since 2008 has been marked by declining private sector debt. This implies that investments of the private sectors lagged behind their savings and that debt reductions were a consequence of excessive indebtedness in the pre-crisis period. Following the 2012 austerity package the year 2015 demonstrates that the private sector indeed continues to drive down its indebtedness levels despite the fact that state debt stagnated. This implies that the decline of private debt was not created by the crowding-out effect of the public deficits.

The presented data indicate also that the crowding-out effect of the public deficits was not a key explanatory factor of investment dynamics.

\subsection{The Ricardian equivalence principle and private consumption}

According to the Ricardian equivalence theorem (Barro, 1974) a reduced deficit stimulates aggregate demand and economic growth because based on the theory of rational expectations people would expect lower taxes in the future considering that the state would accrue lower debt and as a result avoid higher principal and interest expenses. Private consumption would be affected in the opposite direction if increased general government expenditures created a larger deficit. This is expected to create pessimistic expectations that result in reductions of private consumption with a very short time lag.

A notable increase of the general government deficit in 2009 shown in Figure 2 did stifle an important part of effective demand as shown in Figure 6. This becomes more evident if we observe the consumer confidence indicator.

Figure 6: Consumer confidence indicator, seasonally adjusted monthly data and real annual growth of private consumption, Slovenia, 2005-15

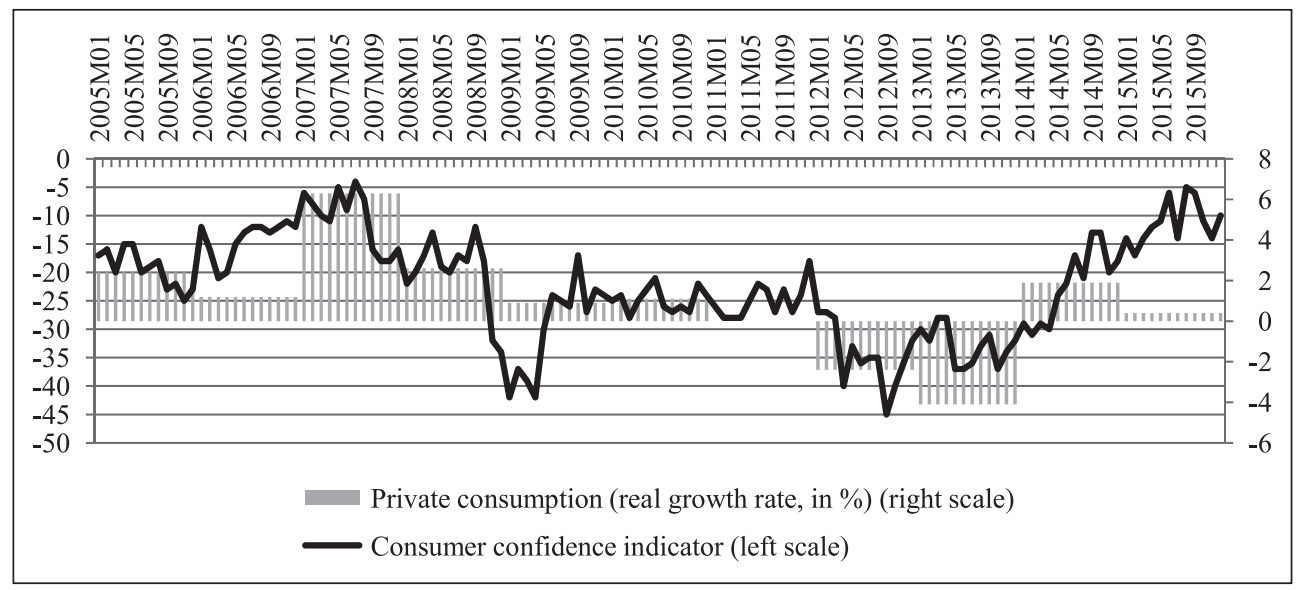

Source: SORS (2017) 
The expectations for the coming year about the financial position of households, the general economic situation, the unemployment rate and household savings that are reflected by the consumer confidence indicator (see Figure 6, left scale) fell dramatically almost instantly. This had an almost immediate negative impact on expectations, but real growth of private consumption remained positive, as Figure 6 (right scale) shows.

In the following year the general government deficit remained practically unaltered, expectations improved but this was not accompanied with increased growth of private consumption. This indicates that expectations were not the only determinant of private consumption.

Also, a larger increase of the deficit in 2013 that resulted due to bank restructuring and resolution negatively influenced expectations but even though the expectations were not at their lowest levels in the analyzed period there was a substantial drop of private consumption. It seems at first glance that the described changes of private consumption are in line with the Ricardian equivalence principle.

However, circumstances characteristic for 2012 and the 2014-2015 period indicate that the Ricardian equivalence principle does not explain the dynamics of private consumption. As already mentioned, austerity was systematically exercised in 2012 and as a result the general government deficit declined.

However, expectations worsened both in 2012 and in the flowing year resulting in reduced private consumption. Austerity practiced in 2012 thus did not trigger the Ricardian equivalence principle that could have been easily noticed. In 20142015, the deficit declined further, expectations improved notably but the growth of private consumption was minimal, especially in 2015. This implies that there were some other important private consumptions determinants aside from the Ricardian equivalence principle.

\subsection{Domestic competitiveness and export}

A comparison of export and government spending (see Figure 7) also fails to provide any obvious support for the effects on domestic competitiveness. Cuts in general government expenditures and the resulting slowdown in the domestic market were not offset by exports sufficiently enough to overpower other export determinants.

Conditions on the domestic market, that were to be created by the austerity policy, did not assume the role of an important export determinant. By shrinking the domestic market export could not be encouraged in Slovenia. 
Figure 7: Nominal growth of government expenditures and export, Slovenia, $2002-15$

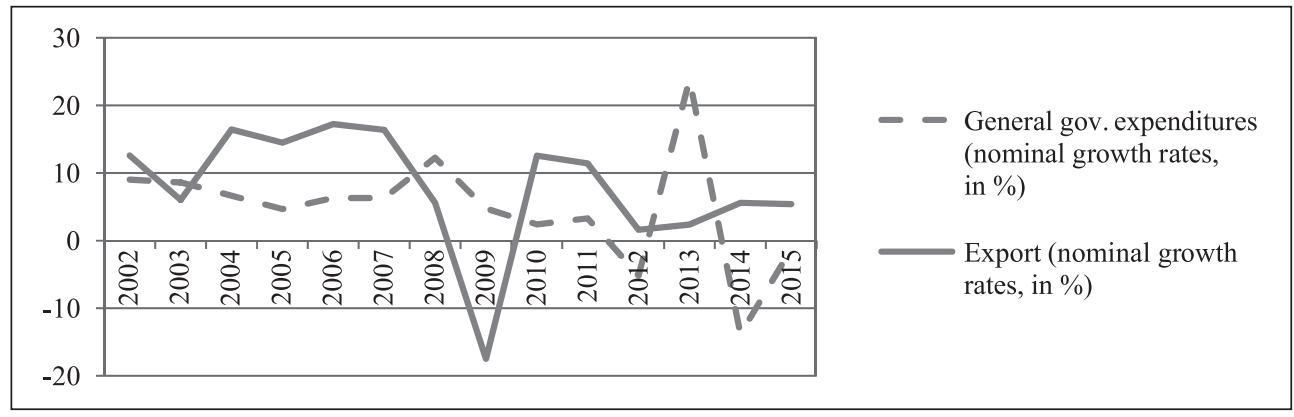

Source: SORS (2017)

According to the Keynesian tradition, relative labour costs, inflation, the exchange rate, global markets and interest rate dynamics can be determinants of exports (Sylos-Labini, 1974; Burbidge, 1979). Considering that the larger trading partners are mostly members of the euro area, the exchange rate policy and interest rate dynamics cannot play an important role. The key determinant of Slovenia's exports is thus demand for Slovenian goods and services in foreign markets. Year-to-year fluctuations in Slovenia's exports can be practically completely explained by the changes in the economic activity of its most important trading partners.

\subsection{Austerity policy and economic growth}

The above analysis of conditions in Slovenia after the 2009 crisis has shown that the dynamics of investment, final household expenditure and exports cannot be explained with effects that are expected to emerge due to exercising austerity. Austerity policy in 2012 did not generate the expected effects neither on economic growth nor on the general government balance. If we observe economic growth, we see that changes of government expenditures created mostly the opposite effects than predicted by the implemented austerity policy.

In 2009, both government spending and government revenues positively affected economic growth (IMAD, 2009). Government spending increased while revenues decreased (Table 1). In Slovenia in 2009, government expenditure on for example social security, health care, education, pensions and unemployment compensation thus created a stabilising effect that also characterised some other countries (Tajnikar and Došenović Bonča, 2012; Ghilarducci et al., 2012). Such expenditures sustained effective demand in the most crucial period, i.e. at the start of the crisis when its effects were still smaller and could thus be more easily managed. It is due to this stabilisation effect of the public sector that Slovenia also experienced the socalled "Keynesian moment" (Seccareccia, 2012: 64). 
To some extent, the stabilisation effects brought by the increased government spending also persisted in 2010-2011. Government revenues increased and thus negatively influenced economic growth, but general government expenditures excluding investment grants and other capital transfers $(\Delta(\mathrm{g}+\mathrm{GI}+\mathrm{GC}))$ also continued to rise. Considering that at reasonable values of the marginal propensity to consume government purchases multipliers are larger than tax multipliers we can even without the estimates of specific values of such multipliers conclude (Galbraith and Darity, 1994; Davidson, 2011) that especially in 2011 the negative effects of increasing government revenues on effective demand were weak. This remained unchanged until 2012 when a package of austerity measures was implemented to reduce general government expenditures (excluding interest and investment grants and other capital transfers) for EUR 588 million. In the following periods, especially in 2014, the government continued to decelerate domestic effective demand by maintaining surplus of revenues over expenditures.

Table 1: Annual change in the nominal value of effective demand elements, in million EUR, Slovenia, 2008-15

\begin{tabular}{|r|r|r|r|r|r|r|}
\hline Year & $\Delta(\mathrm{G}+\mathrm{GI}+\mathrm{GC})$ & $\Delta(\mathrm{g}+\mathrm{GI}+\mathrm{GC})$ & \multicolumn{1}{c|}{$\Delta \mathrm{T}$} & \multicolumn{1}{c|}{$\Delta \mathrm{C}$} & \multicolumn{1}{c|}{$\Delta \mathrm{I}$} & \multicolumn{1}{c|}{$\Delta \mathrm{X}$} \\
\hline 2008 & 1,840 & 1,776 & 1,312 & 648 & 650 & 1,327 \\
\hline 2009 & 731 & 838 & -801 & -57 & $-3,973$ & $-4,387$ \\
\hline 2010 & 302 & 323 & 502 & 301 & -382 & 2,604 \\
\hline 2011 & 484 & 107 & 179 & 134 & 246 & 2,659 \\
\hline 2012 & -980 & -588 & 31 & 52 & $-1,202$ & 415 \\
\hline 2013 & 3,974 & 64 & 244 & -792 & 147 & 624 \\
\hline 2014 & $-3,259$ & -27 & 520 & 622 & 56 & 1,513 \\
\hline 2015 & -184 & 203 & 620 & -120 & 420 & 1,542 \\
\hline
\end{tabular}

Note: $\mathrm{G}$ - sum of final government consumption expenditure and investment grants and other capital transfers, g - final government consumption expenditure, GI - government investment, GC - final household consumption supported by transfer incomes from public sources, $\mathrm{T}$ - general government revenues, $\mathrm{C}$ - final household expenditure-private, I private investment, $\mathrm{X}$ - export

Source: SORS (2017)

The extent at which the shaping of general government revenues and expenditures influenced overall effective demand and economic growth of course also depends upon the behaviour of all other elements of effective demand. It is important to consider that after the 2009 crisis the Slovenian economy was characterised by underutilised capacities (see Figure 8) and that in such circumstances all components of effective demand are equally important for growth and investment need not be the sole focus (e.g. Sylos-Labini, 1974; Kornai, 1990). 
Figure 8: Capacity utilisation (in \%) of non-financial corporations (production of non-financial corporations divided by gross fixed assets of non-financial corporations in current prices), Slovenia, 2001-15

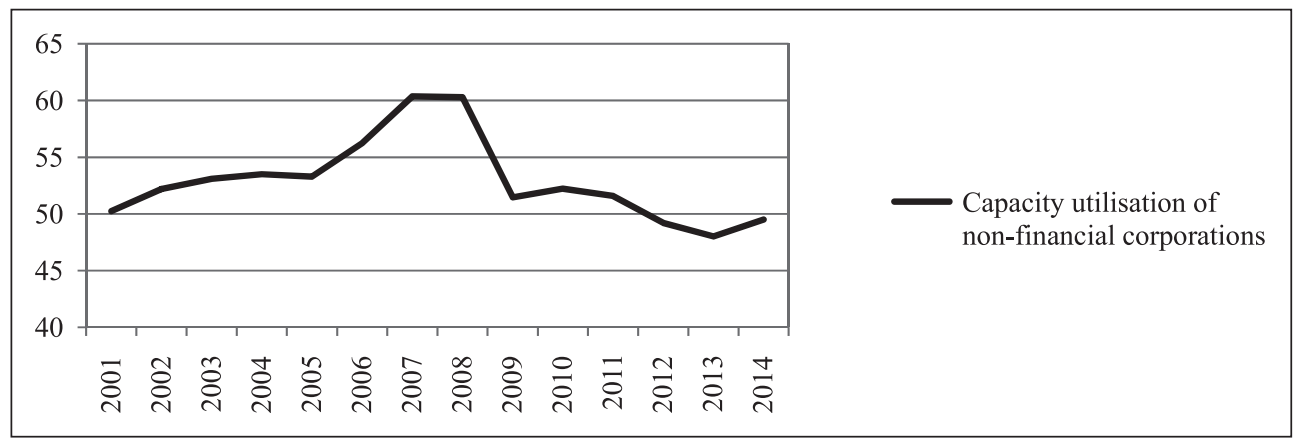

Source: SORS (2017)

As evident from Table 1, private investment played a crucial role in the reduction of effective demand and Slovenia's economic growth in 2009. At that time, increased general government expenditures were not able to offset the negative impacts of the significant drop of private investment given that the decline of private investment was about 5-times larger than the increase of government expenditures. Also in 2010 the increased government expenditures only compensated the downturn in investment activity of the private sector. In 2011, however, both private investment and government expenditures increased the effective demand. With the introduction of austerity in 2012 both private investment and government spending contributed to a decrease of effective demand for about EUR 1.8 billion. In the following periods private investment activity was revived and positively contributed to effective demand. Furthermore, the positive impact of private investments was larger than the influence of government expenditures.

Private investments and their negative impact on effective demand thus explain negative economic growth in Slovenia in 2009 and 2012. The positive impact of investments was characteristic for 2011 and 2015. Other elements of effective demand must have been more influential in 2010, 2013 and 2014.

It is reasonable to expect that in circumstances of underutilised capacities investments no longer play the most important role in effective demand growth and we can conclude that exports became an important determinant of economic growth (see Table 1).

Exports contributed most significantly to the decline in economic growth in 2009 and to the positive growth in 2010 and 2011. In 2009, their negative impact was accompanied by a similar decline in private investment. As evident from Table 1, the negative effect of a lower foreign demand was over 5-times larger than the positive 
effect of government spending on effective demand. A similar conclusion was drawn above for private investment. This implies that the effects of government expenditures were too weak to prevent a radical decline of economic growth in 2009, despite the fact they had some stabilising effects. In 2010 and 2011, positive effects of exports on effective demand played a vital role in economic growth. In 2010, their positive effects were about 8-times stronger than the effects of government expenditures. The positive impacts of exports in 2011 were strengthened by the weak but positive impacts of private investments. It is evident that the rise of exports in 2010 played a vital role in reviving economic growth. What is also important is that in 2010 this economic upturn - and not the reduced general government deficit - created optimistic expectations of households and increased their private consumption.

Unfortunately, in Slovenia the austerity package was enforced in 2012, i.e. during the slowdown of exports (see Figure 7). Given that, as we already mentioned, the level of exports is determined exogenously and cannot be importantly influenced by domestic economic policies, the implementation of austerity measures in 2012 crucially influenced the slowdown of economic growth that started to pick up in 2010 and 2011. Modest export growth also influenced private investments that declined in 2012 and negative pressures on economic growth strengthened by a radical cut in government expenditures. Additionally, the growth of final household private consumption (endogenously) slowed down. They continued to decline also in 2013 despite the fact that in this year both exports and private investment stated to exhibit positive upward trends that were, however, not strong enough to create positive economic growth. A more significant rise of exports and optimistic expectations of households in 2014 explain a notable rise of GDP in this year. In this year the rise of exports was 1.3-times larger than the increase of all other elements of effective demand (see Table 1). In 2015, final household private consumption again decreased slightly slowing down GDP growth due to export and private investment growth.

In the case of Slovenia, imports have no empirical link as a determinant of economic growth. If imports are included through net exports, the value of exports loses its explanatory power. In explaining economic growth in Slovenia since 2008 imports should thus be considered as endogenous. Furthermore, given the surplus of the current account of the balance of payments ever since 2009, imports also did not restrain economic growth (SORS, 2017). It is important to note that the surplus of the current account of the balance of payments is a consequence of reduced indebtedness of the private sector. Decrease of private sector debt requires private savings to exceed private investment and this negatively affects economic growth. It is reasonable to expect that such an imbalance would persist for as long as there is a need for the private sector to reduce its indebtedness.

An interesting effect created through the shaping of effecting demand is revealed if we observe conditions of 2010 and 2011. In 2011, the value of GDP in current 
prices increased compared to 2010 while the growth of GDP in real term was lower in 2011 compared to 2010. In 2011, the increase of elements of effective demand led to a significant increase in prices, especially food and real estate prices. Output prices also increased while the rise of production was smaller (IMAD, 2014). It appears that price increases were due to increased effective demand.

\subsection{Economic growth and the state budget}

As shown by Figure 2, in all years of positive economic growth (2010-2011 and 2014-2015) general government revenues grew faster or nearly as fast as expenditures. Therefore, in these years the general government deficit either stabilised or declined. The correlation between general government revenues and GDP is high (0.93) while this is not true for general government expenditures $(0.5)$. As we have shown, the government expenditures declined substantially only in 2012 when the austerity package was imposed.

If we ignore the developments in 2012 and also exclude the investment grants and other capital transfers, we see that general government expenditures did not have an influential impact on overall effective demand and economic growth. Given the link between GDP and general government revenues they also had a negligible impact on general government revenues. These were mostly dependent on other elements of effective demand that were independent from government expenditures and austerity measures.

As shown by Table 1, it was precisely these other elements of effective demand that encouraged economic growth that thus also led to higher general government revenues and a consequent reduction of the general government deficit. Economic growth in Slovenia in 2014 and 2015 lowered the deficit because other elements that are independent of austerity measures influenced GDP growth more strongly than elements of austerity policy.

In Slovenia, the growth rate of output was lower than the rate of interest for the private sector (Figure 4) and interest rate for public debt (Figure 9) after 2008. According to Domar (1944) and Pasinetti (1997), the debt-to-GDP ratio should increase in such circumstances (e.g. Taylor et al., 2012). Based on this notion, Pasinetti (1997) defined the relationship between the debt-to-GDP ratio and the amount of taxes required to pay interest. It is reasonable to conclude that in Slovenia the debt crisis was generated when GDP growth rates became negative and interest rates for public debt surged. In practice lowering of general budget debt becomes much more difficult considering that it burdens the budget also with higher interests on public debt. Given that the circumstances were opposite prior to crisis it is understandable that preserving low public debt was much easier (see Figure 9). 
Figure 9: Nominal interest rates (in \%) for issued public bonds (horizontal lines) and growth of nominal GDP (in \%) (dotted line), Slovenia, 2004-15

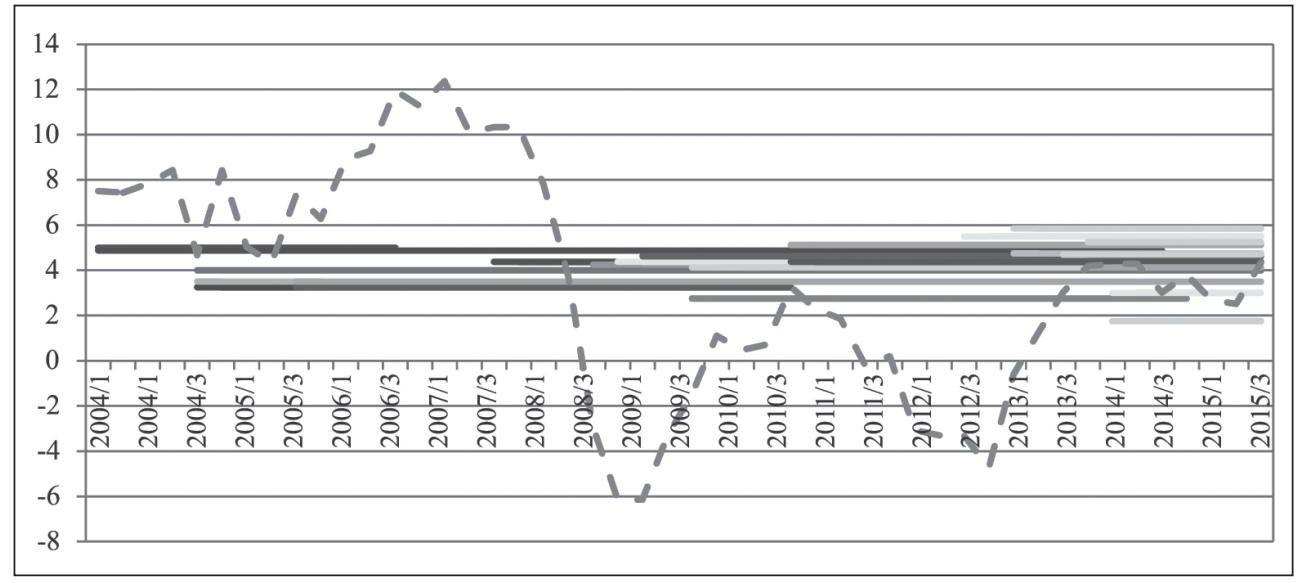

Note: Horizontal lines show interest rates for different bonds issued since 2004 .

Sources: Ministry of Finance of RS (2017), SORS (2017)

As shown by Figure 9 in Slovenia, interest rates for public debt rose after the outburst of economic crisis in 2009. As we have shown, the general government deficit and public debt rose shortly after crisis, but this posed an insignificant threat to the economy given the initial low level of indebtedness of the general government sector and total gross external debt. It did, however, cause a reaction of international financial markets and this led to the rise of interest rates for public debt. This evolved in 2010 and 2011 when economic growth picked up after the 2009 drop. With no clear opposition and even with the support of policymakers, rating agencies encouraged the collusive behaviour of financial institutions and oligopolistic interest rate increases. The pressure from international financial markets has thus become one of the fundamental reasons for implementing austerity in Slovenia.

It seems that at least from this viewpoint Slovenia closely resembles other countries dedicated to austerity (Frieden, 2009: 7; Konzelmann, 2014: xlvi). The pressure of financial institutions on the one hand maintains high interest rates and advocates the implementation of austerity measures that constrict economic growth on the other hand. It is not possible to decrease the debt-to-GDP ratio in such circumstances without significant costs. In 2014 and 2015, these high costs were reflected in the loss of effective demand due to effective demand of the general government sector that was lower than expected given economic growth and general government revenues due to high interest payments on public debt. 


\section{Results and discussion}

The authors believe that in the case of Slovenia it is not possible to find sufficiently strong evidence that the crowding-out effect of public deficits impacted private investment, that the Ricardian equivalence principle explains the impacts on household consumption and that the effects on domestic competitiveness were crucial for the level of exports. When making such a conclusion one needs to consider that in Slovenia austerity was imposed only in one year after the initial outburst of crisis. This is thus a case of investigating the effects of "isolated fiscal shocks". Some authors argue that multi-year plans are a better way of studying the effects of fiscal policy because in the real-world governments typically adopt multiyear budget laws (Alesina, Favero and Giavazzi, 2018).

Conditions is Slovenia every year since 2008 do not support the conclusion by, for example, Alesina, Favero and Giavazzi (2018) that austerity measures based on expenditure cuts are much less costly than those performed on the tax side in reducing public debt and supporting economic growth. The Slovenian case shows that the tax revenues are dependent on the economic growth while economic growth is determined strongly by individual elements of effective demand that are independent of government expenditures. In such circumstances government expenditures have to adjust to tax revenues. In conditions of weak growth government expenditures cuts should not overpower the impact of tax revenues on the government budget. In conditions of strong economic growth, however, fast growth of tax revenues should be used to decrease the budget deficit.

Slovenia's experiences illustrate that the negative effects of austerity can be offset by alterations of those effective demand components that can be influenced by the economic policy and by adjusting the intensity of austerity measures to the dynamics of those effective demand elements that are not directly linked to economic policy actions. Keynesian demand management is thus vital for countries with economic circumstances such as the ones experienced in Slovenia.

\section{Conclusion}

Results presented in this paper confirm the hypothesis that the case of Slovenia does not support the theoretically predicted effects of austerity. The empirical analysis based on data for Slovenia does not confirm the theoretically expected crowding-out effect, the Ricardian equivalence principle and domestic competitiveness effect on economic growth and budget balance. The case of Slovenia also fails to confirm the hypothesis that fiscal consolidations based on expenditure cuts are much less costly than those performed on the tax side which is commonly accepted in empirical studies on austerity policy. The presented results reveal a complex relationship between fiscal 
policy measures and economic growth by taking into consideration also the stage of the economic cycle in which austerity is enacted and country specifics. Authors conclude that during economic booms deficits should be decreased through tax increases but in times of weak economic growth expenditure cuts can endanger both economic growth and the budget balance. Authors also note that the studies of austerity policies should be based on a detailed analysis of specific circumstances of individual countries given that econometric analyses based on data for a large number of countries provide very general oversimplified conclusions. This is particularly important if studies of impacts of austerity are to be used for the purpose of policy design and implementation. Very broad conclusions of many studies based on a set of heterogeneous countries do not inform policy making as they fail to incorporate country-specific features and the different stages of their respective economic cycles.

\section{References}

Alesina, A., Perotti, R., Tavares, J. (1998) "The political economy of fiscal adjustments", Brookings Papers on Economic Activity, Vol. 29, No. 1, pp. 197-266.

Alesina, A., Ardagna, S. (1998) "Tales of fiscal adjustment”, Economic Policy, Vol. 13, No. 27, pp. 498-545, doi: 10.1111/1468-0327.00039.

Alesina, A., Ardagna, S. (2009) "Large changes in fiscal policy: Taxes versus spending”, National Bureau of Economic Research Working Paper No. 15438.

Alesina, A., Favero, C.A., Giavazzi, F. (2018) "What do we know about the effects of austerity?", National Bureau of Economic Research Working Paper No. 24246.

Auerbach, A.J., Gorodnichenko, Y. (2012) "Measuring the output responses to fiscal policy", American Economic Journal: Economic Policy, Vol. 4, No. 2, pp. 1-27, doi: 10.1257/pol.4.2.1.

Bank of Slovenia (2017) "Gross external debt", Monthly Bulletin, Vol. XXVI, No. 1, pp. II. 92-33.

Barro, R. (1974) “Are government bonds net wealth?", Journal of Political Economy, Vol. 82, No. 6, pp. 1095-117, doi: 10.1086/260266.

Blanchard, O.J., Perotti, R. (2002) "An empirical investigation of the dynamic effects of changes in government spending and revenues on output", Quarterly Journal of Economics, Vol. 117, No. 4, pp. 1329-1368, doi: 10.1162/0033553 02320935043.

Boyer, R. (2012) "The four fallacies of contemporary austerity policies: The lost Keynesian legacy”, Cambridge Journal of Economics, Vol. 36, No. 1, pp. 283-312, doi: 10.1093/cje/ber037.

Burbidge, J.B. (1979) "The international dimension”. In Eichner, A.S. ed., A guide to post Keynesian economics, London: The MacMillan Press. 
Cambridge Journal of Economics (2013) Special issue: Prospects for the Eurozone. Vol. 37, No. 3.

Chang, H.J. (2012) 23 Things they don't tell you about the capitalism, New York: Bloomsbury Press.

Cottrell, A. (2013) "Truth and beauty in macroeconomics". In Jespersen, J., Ove Madsen, M. eds., Teaching post Keynesian economics, Cheltenham, UK, Northampton, MA, USA: Edward Elgar.

Crotty, J. (2012) "The great austerity war: what caused the US deficit crisis and who should pay to fix it?", Cambridge Journal of Economics, Vol. 36, No. 1, pp. 79-104, doi: 10.1093/cje/ber029.

Davidson, P. (2011) Post Keynesian macroeconomic theory, Cheltenham, UK, Northampton, USA: Edward Elgar.

Domar, E. (1944) "The burden of debt and the national income", American Economic Review, Vol. 34, No. 4, pp. 798-827.

Eurostat (2017) Eurostat database, retrieved from http://ec.europa.eu/eurostat/data/ database.

Frieden, J.A. (2009) Global imbalances, national rebalancing and the political economy of recovery, Center for geoeconomic studies and international institutions and global governance program working paper.

Galbraith, J.K., Darity, W. (1994) Macroeconomics, Boston: Houghton Mifflin Company.

Galbraith, J.K. (2014) The end of normal, New York: Simon and Shuster.

Ghilarducci, T., Saad-Lessler, J., Fisher, E. (2012) "The macroeconomic stabilization effects of social security and 401(k) plans", Cambridge Journal of Economics, Vol. 36, No. 1, pp. 237-251, doi: 10.1093/cje/ber040.

Giavazzi, F., Pagano, M. (1990) "Can severe fiscal contractions be expansionary? Tales of two small European countries". In Blanchard, O., Ficher, I. eds., NBER macroeconomics annual 1990, Cambridge, MA: MIT Press.

IMAD (2009) "Public finance", Slovenian Economic Mirror, Vol. XV, No. 5, pp. $22-24$.

IMAD (2013) Development report 2013, Ljubljana: Institute of Macroeconomic Analysis and Development of the Republic of Slovenia.

IMAD (2014) "Prices", Slovenian Economic Mirror, Vol. XX, No. 10, pp. 15-17.

Konzelmann, S.J. (2014) "Introduction". In Konzelmann, S.J. ed., The economics of austerity, Cheltenham, UK, Northampton, MA, USA: An Elgar Research Collection.

Kornai, J. (1990) Vision and reality, market and state: Contradictions and dilemmas revisited, London, New York: Routledge.

Krugman, P. (2012) End this depression now, New York, London: W.W. Norton and Company. 
Matsaganis, M., Leventi, C. (2014) "The distributional impact of austerity and the recession in Southern Europe", South European Society and Politics, Vol. 19, No. 3, pp. 393-412, doi: 10.1080/13608746.2014.947700.

Ministry of Finance of RS (2017) Government bonds, retrieved from http://www.

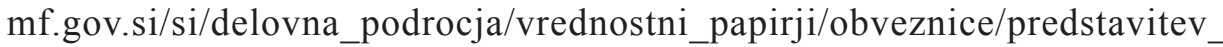
obveznic/

Pasinetti, L.L. (1997) “The social 'burden' of high interest rates”. In Arestis, P., Palma, G., Sawyer, M. eds., Capital controversy, post Keynesian economics and the history of economic thought: Essays in honour of Geoff Harcourt, Volume One, London: Routledge.

Perotti, R. (1996) "Fiscal consolidation in Europe: Composition matters", The American Economic Review, Vol. 86, No. 2, pp. 105-110.

Pržiklas Družeta, R., Škare. M. (2017) "Fiscal austerity policy impact on welfare", Review of Innovation and Competitiveness, Vol. 3, No. 1, pp. 95-118.

Ramey, V.A. (2016) "Macroeconomic shocks and their propagation". In Taylor, J.B., Uhlig, H. eds., Handbook of Macroeconomics, Amsterdam: Elsevier.

Reinhard, C., Rogoff, K. (2009) This time is different. Eight centuries of financial folly, Princeton: Princeton University Press.

Romer, C., Romer, D.H. (2010) "The macroeconomic effects of tax changes: estimates based on a new measure of fiscal shocks", American Economic Review, Vol. 100, No. 3, pp. 763-801, doi: 10.1257/aer.100.3.763.

Seccareccia, M. (2012) "The role of public investment as principal macroeconomic tool to promote long-term growth: Keynes's legacy", International Journal of Political Economy, Vol. 40, No. 4, pp. 62-82, doi: 10.2753/IJP0891-1916400403.

SORS (2017) SI-STAT data portal, retrieved from http://pxweb.stat.si/pxweb/ dialog/statfile1.asp.

Stiglitz, J. (2013) The price of inequality, New York, London: W.W. Norton and Company.

Sylos-Labini, P. (1974) Trade unions, inflation and productivity, Lexington: Lexington Books, Saxon House.

Tajnikar, M., Došenović Bonča, P. (2012) "Public sector austerity: Path to crisis or path to recovery?", CESifo Forum, Vol. 13, No. 4, pp. 64-69.

Taylor, T., Proaño, C.R., de Carvalho, L., Barbosa, N. (2012) "Fiscal deficits, economic growth and government debt in the USA", Cambridge Journal of Economics, Vol. 36, No. 1, pp. 189-204, doi: 10.1093/cje/ber041. 


\title{
Politike mjera štednje, ekonomski rast i fiskalna ravnoteža: lekcije iz
} Slovenije ${ }^{1}$

\author{
Petra Došenović Bonča ${ }^{2}$, Maks Tajnikar ${ }^{3}$
}

\begin{abstract}
Sažetak
Osnova rada predstavlja empirijsku analizu utjecaja politika mjera štednje na ekonomski rast Slovenije kroz istraživanje učinaka efekta istiskivanja, principa Rikardijanske ekvivalencije i efekta domaće konkurentnosti na ekonomski rast Slovenije. Koristeći se deskriptivnom metodom, autori proučavaju determinante rasta $i$ utjecaj fiskalne politike na empirijski odnos između javnog duga $i$ ekonomskog rasta. Rezultati analize pokazuju da su mjere štednje u Sloveniji implementirane kroz kratka vremenska razdoblja unutar kojih nije moguće pronaći uvjerljive argumente o teorijskim ili empirijskim učincima koji proizlaze iz literature. Posljedično, autori potvrđuju tezu kako oživljavanje ekonomskog rasta Slovenije, koji je u navedenom periodu uravnotežio državni proračun te osnažio fiskalni položaj, nije ovisilo o provedenim mjerama štednje.
\end{abstract}

Ključne riječi: mjere štednje, ekonomski rast, državni dug, Slovenija

JEL klasifikacija: E12, E6

${ }^{1}$ Istraživanje je sufinancirano od strane Javne agencije za istraživačke aktivnosti Republike Slovenije [broj projekta P5-0117 (A)].

${ }^{2}$ Izvanredna profesorica, Sveučilište u Ljubljani, Ekonomski fakultet, Kardeljeva ploščad 17, 1000 Ljubljana, Slovenija. Znanstveni interes: ekonomska teorija, ekonomika zdravstva. Tel.: +38615892 448. Fax: +38615892 698. E-mail: petra.d.bonca@ef.uni-lj.si. Osobna web stranica: http://www.ef.uni-lj.si/person/Petra-Dosenovic-Bonca. (osoba za kontakt).

3 Redoviti profesor, Sveučilište u Ljubljani, Ekonomski fakultet, Kardeljeva ploščad 17, 1000 Ljubljana, Slovenija. Znanstveni interes: ekonomska teorija, poduzetništvo, ekonomika zdravstva. Tel.:+38615892 574.Fax: +38615892 698. E-mail: maks.tajnikar@ef.uni-lj.si. Osobna web stranica: http://www.ef.uni-lj.si/osebe/Maks-Tajnikar. 